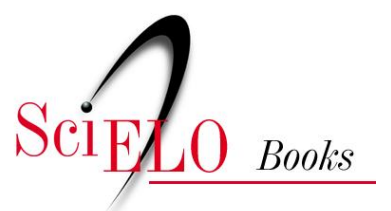

\title{
Últimos dias
}

\author{
Euclides da Cunha
}

CUNHA, E. Últimos dias. In: Os sertões [online]. Rio de Janeiro: Centro Edelstein de Pesquisas Sociais, 2010. pp. 462-509. ISBN: 978-85-7982-007-6. https://doi.org/10.7476/9788579820076.0009.

\section{() poumain}

This work is free of known copyright restrictions. http://creativecommons.org/publicdomain/mark/1.0/

Este trabalho está livre de restrições de direito de autor e/ou de direitos conexos conhecidas. http://creativecommons.org/publicdomain/mark/1.0/

Esta obra está libre de restricciones conocidas de derechos autorales. http://creativecommons.org/publicdomain/mark/1.0/ 


\section{ÚLTIMOS DIAS}

\section{Capítulo I}

I. O estrebuchar dos vencidos. Os prisioneiros.

II. Depoimento de uma testemunha.

III. Titãs contra moribundos. Em torno das cacimbas. Sobre os muradais da igreja nova.

IV. Passeio dentro de Canudos.

V. O assalto. Notas de um diário.

VI. O fim. Crânio do Conselheiro.

VII. Duas linhas.

\section{O estrebuchar dos vencidos}

Sucedeu, então, um fato extraordinário de todo em todo imprevisto.

O inimigo desairado revivesceu com vigor incrível. Os combatentes, que o enfrentavam desde o começo, desconheceram-no. Haviam-no visto, até aquele dia, astucioso, negaceando na maranha das tocaias, indomável na repulsa às mais valentes cargas, sem par na fugacidade com que se subtraía aos mais improvisos ataques. Começaram a vê-lo heroico.

A constrição de milhares de baionetas circulantes estimulara-o, enrijara-o; e dera-lhe, de novo, a iniciativa nos combates. Estes principiaram desde 23, insistentes como nunca, sulcando todos os pontos, num rumo girante, estonteador, batendo, trincheira por trincheira, toda a cercadura do sítio.

Era como uma vaga revolta, desencadeando-se num tumulto de voragem. Repelida pelas tranqueiras avançadas de leste, refluía numa esteira fulgurante de descargas na direção do Cambaio; arrebentava nas encostas que ali descem, clivosas, para o rio: recebia, em cima e em cheio, a réplica das guarnições que as encimavam, e rolava, envesgando para o norte, acachoando dentro do álveo do Vaza-Barris, até se despedaçar de encontro às paliçadas que naquele sentido o represavam; volvia vertiginosamente ao sul; viam-na ondular, célere e agitante, por dentro do arraial, atravessando-o, e logo depois marulhar, recortada de tiros, na base dos primeiros esporões da Favela; saltava de novo para o leste, torcida, embaralhada, estrepitosa - e batia a esquerda do $5^{\circ}$ da Bahia; era repelida; caía adiante sobre a barreira do $26^{\circ}$, era repelida; retraía-se daquele ponto para o centro da praça, inflectindo, serpeante, rápida, e quebrava-se, um minuto depois, sobre a linha negra; passava indistinta, mal vista ao clarão fugaz das fuzilarias, e corria mais uma vez para o norte, chofrando os mesmos pontos, repulsada sempre e atacando sempre, num remoinhar irreprimível e rítmico de ciclone... Parava. Súbita quietude substituía o torvelinho furioso. Absoluto silêncio descia sobre os dois campos. Os sitiantes deixavam a formatura do combate. 
Mas repousavam alguns minutos breves.

Um estampido atroava na igreja nova, e viam-se-lhe sobre as cimalhas fendidas, engrimponados nas pedras vacilantes, vultos erradios, cruzando-se, mal firmes sobre escombros, correndo numa ronda doida. Tombavam-lhes logo em cima, revessadas de todos os trechos artilhados, lanternetas desabrolhando em balas. Não as suportavam. Desciam, em despenhos e resvalos de símios, daqueles muradais Perdiam-se nos pardieiros próximos ao santuário. E ressurgiam, inopinadamente, junto de um ponto qualquer da linha. Batiam-no, eram repelidos; atacavam as outras trincheiras anexas, eram repelidos; caíam sobre as que se sucediam, e prosseguiam no giro, arrebatados na rotação enorme dos assaltos.

Os que na véspera desdenhavam o adversário entaipado naqueles casebres assombravam-se. Como nos maus dias passados, mais intensamente ainda, jugulou-os o espanto.

Cessaram os desafios imprudentes. Determinou-se, de novo, que não soassem as cornetas. Só havia um toque possível — o de alarma — e este o inimigo eloquentemente o dava.

Despovoaram-se os cerros. Terminou o fanfarrear dos que por ali se estadeavam, desafiando tiros. Valentes de fama, premunidos de cautelas, fraldejavam-nos, às rebatinhas pelas passagens cobertas, curvando-se, e transpondo aos pinchos os pontos enfiados. Tornaram-se outra vez dificílimas as comunicações. Os comboios desde que apontavam ao sul na crista dos morros, pela estrada do Calumbi, começavam a ser alvejados; desciam-nos precípites e alguns comboieiros vinham cair feridos no último passo, à entrada do acampamento.

\section{A situação tornou-se, de repente, inaturável.}

Não se compreendia que os jagunços tivessem ainda, após tantos meses de luta, tanta munição de guerra. E não a poupavam. Em certas ocasiões, no mais agudo dos tiroteios, pairava sobre os abarracamentos um longo uivar de ventania forte.

Projetis de toda a espécie, sibilos finos de Mannlicher e Mauser, zumbidos cheios e sonoros de Comblain, rechinos duros de trabucos, rijos como os de canhões-revólveres, transvoando a todos os pontos: sobre o âmbito das linhas; sobre as tendas próximas aos quartéis-generais; sobre todos os morros até ao colo abrigado da Favela, onde sesteavam cargueiros e feridos; sobre todas as trilhas; sobre o álveo longo e tortuoso do rio e sobre as depressões mais escondidas; resvalando com estrondo pela tolda de couro da alpendrada do hospital de sangue e despertando os enfermos retransidos de espanto; despedaçando vidros na farmácia militar, anexa; varando, sem que se explicasse tal abatimento de trajetória, as choupanas de folhagens, a um palmo das redes, de onde pulavam, surpreendidos, combatentes exaustos; percutindo, como pedradas rijas, as paredes espessas dos casebres da comissão de engenharia e quartel-general da $1^{\mathrm{a}}$ coluna; zimbrando, em sibilos de vergastas, o pano das barracas; e fora das barracas, dos casebres, dos toldos, das tendas, estralando, ricochetando, ressaltando, desparzindo nos flancos das colinas, sobre as placas xistosas, quebrando-as e esfarelando-as em estilhas, numa profusão incomparável de metralha...

A luta atingia febrilmente o desenlace da batalha decisiva que a remataria. Mas aquele paroxismo estupendo acovardava os vitoriosos.

\section{Os prisioneiros}

Chegaram no dia 24 os primeiros prisioneiros.

Voltando triunfante, a tropa, que a princípio colhera em caminho meia dúzia de crianças, de quatro a oito anos, por ali dispersas e tolhidas de susto, ao esquadrinhar melhor os casebres conquistados encontrara algumas mulheres e alguns lutadores, feridos.

Estes últimos eram poucos e vinham em estado deplorável: trôpegos, arrastados, exaustos.

Um suspenso pelas axilas entre duas praças, meio desmaiado, tinha, diagonalmente, sobre o peito nu, a desenhar-se num recalque forte, a lâmina do sabre que o abatera. Outro, o velho curiboca desfalecido que não vingara disparar a carabina sobre os soldados, parecia um desenterrado claudicante. Ferido, havia meses, por estilhaços de granada, no ventre, ali tinha dois furos, de bordos vermelhos e cicatrizados, por onde extravasavam os intestinos. A voz morria-lhe na garganta, num regougo opresso. Não o interrogaram. Posto à sombra de uma barranca continuou na agonia, que o devorava, talvez havia três meses. 
Algumas mulheres fizeram revelações: Vila-Nova seguira, na véspera, para a Várzea da Ema. Sentia-se, já há tempos, fome no arraial, sendo quase todos os mantimentos destinados aos que combatiam; e, revelação mais grave, o Conselheiro não aparecia desde muito.

Ainda mais, trancadas todas as saídas, começara para todos, lá dentro, o suplício crescente da sede.

Não iam além as informações. Os que as faziam, inteiramente sucumbidos, mal respondiam às perguntas. Um único não refletia na postura abatida as provações que vitimavam os demais. Forte, de estatura meã e entroncada - espécime sem falhas desses hércules das feiras sertanejas, de ossatura de ferro articulando em juntas nodosas e apontando em apófises rígidas - era, tudo o revelava, um lutador de primeira linha, talvez um dos guerrilheiros acrobatas que se dependuravam ágeis nos dentilhões abalados da igreja nova. Primitivamente branco, requeimara-selhe inteiramente o rosto, mosqueado de sardas. Pendia-lhe à cintura, oscilante, batendo abaixo do joelho, a bainha vazia de uma faca de arrasto. Fora preso em plena refrega. Conseguira derribar, num arremessão valente, três ou quatro praças; lograria escapar se não caísse, tonto, ferido de esconso por uma bala na órbita esquerda. Entrou, jugulado como uma fera, na tenda do comandante da $1^{\text {a }}$ coluna. Ali o largaram. O resfôlego precípite arguia o cansaço da luta. Alevantou a cabeça e o olhar singular que lhe saía dos olhos - um cheio de brilhos, outro cheio de sangue - assustava. Tartamudeou, desajeitadamente, algumas frases mal percebidas. Tirou o largo chapéu de couro e, ingenuamente, fez menção de sentar-se.

\section{Era a suprema petulância do bandido!}

Brutalmente repelido, rolou aos tombos pela outra porta, escorjado sob punhos possantes.

Fora, passaram-lhe, sem que protestasse, uma corda de sedenho na garganta. E, levado aos repelões para o flanco direito do acampamento, o infeliz perdeu-se com os sinistros companheiros que o ladeavam no seio misterioso da caatinga.

\section{A degola}

Chegando à primeira canhada encoberta, realizava-se uma cena vulgar. Os soldados impunham invariavelmente à vítima um viva à República, que era poucas vezes satisfeito. Era o prólogo invariável de uma cena cruel. Agarravam-na pelos cabelos, dobrando-lhe a cabeça, esgargalando-lhe o pescoço; e, francamente exposta a garganta, degolavamna. Não raro a sofreguidão do assassino repulsava esses preparativos lúgubres. O processo era, então, mais expedito: varavam-na, prestes, a facão. rápido...

Um golpe único, entrando pelo baixo ventre. Um destripamento

Tínhamos valentes que ansiavam por essas covardias repugnantes, tácita e explicitamente sancionadas pelos chefes militares. Apesar de três séculos de atraso, os sertanejos não lhes levavam a palma no estadear idênticas barbaridades. 


\section{Capítulo II}

\section{Depoimento do autor}

Desvendemo-las rudemente.

Deponhamos.

O fato era vulgar. Fizera-se pormenor insignificante.

Começara sob o esporear da irritação dos primeiros reveses, terminava friamente feito praxe costumeira, minúscula, equiparada às últimas exigências da guerra. Preso o jagunço válido e capaz de aguentar o peso da espingarda, não havia malbaratar-se um segundo em consulta inútil. Degolava-se; estripava-se. Um ou outro comandante se dava o trabalho de um gesto expressivo. Era uma redundância capaz de surpreender.

Dispensava-a o soldado atreito à tarefa

Esta era, como vimos, simples. Enlear ao pescoço da vítima uma tira de couro, num cabresto ou numa ponta de chiquerador; impeli-la por diante; atravessar entre as barracas, sem que ninguém se surpreendesse; e sem temer que se escapasse a presa, porque ao mínimo sinal de resistência ou fuga um puxão para trás faria que o laço se antecipasse à faca e o estrangulamento à degola. Avançar até à primeira covanca profunda, o que era um requinte de formalismo; e, ali chegados esfaqueá-la. Nesse momento, conforme o humor dos carrascos, surgiam ligeiras variantes. Como se sabia, o supremo pavor dos sertanejos era morrer a ferro frio, não pelo temor da morte senão pelas suas consequências, porque acreditavam que, por tal forma, não se lhes salvaria a alma.

Exploravam esta superstição ingênua. Prometiam-lhes não raro a esmola de um tiro, à custa de revelações. Raros o faziam. Na maioria emudeciam, estoicos, inquebráveis — defrontando a perdição eterna. Exigiam-lhes vivas à República. Ou substituíam essa irrisão dolorosa pelo chasquear franco e insultuoso de alusões cruéis, num coro hilar e bruto de facécias pungentes. E degolavam-nos, ou cosiam-nos a pontaços. Pronto. Sobre a tragédia anônima, obscura, desenrolando-se no cenário pobre e tristonho das encostas eriçadas de cactos e pedras, cascalhavam rinchavelhadas lúgubres, e os matadores volviam para o acampamento. Nem lhes inquiriam pelos incidentes da empresa. $\mathrm{O}$ fato descambara lastimavelmente à vulgaridade completa. Os próprios jagunços, ao serem prisioneiros, conheciam a sorte que os aguardava. Sabia-se no arraial daquele processo sumaríssimo e isto, em grande parte, contribuía para a resistência doida que patentearam. Render-se-iam, certo, atenuando os estragos e o aspecto odioso da campanha, a outros adversários. Diante dos que lá estavam, porém, lutariam até à morte.

E quando, afinal jugulados, eram conduzidos à presença dos chefes militares, iam conformados ao destino deplorável. Revestiam-se de serenidade estranha e uniforme, inexplicável entre lutadores de tão variados matizes, e tão discordes caracteres, mestiços de toda a sorte, variando, díspares, na índole e na cor.

Alguns se aprumavam com altaneria incrível, no degrau inferior e último da nossa raça. Notemos alguns exemplos.

Um negro, um dos raros negros puros que ali havia, preso em fins de setembro, foi conduzido à presença do comandante da $1^{\mathrm{a}}$ coluna, general João da Silva Barbosa. Chegou arfando, exausto da marcha aos encontrões e do recontro em que fora colhido Era espigado e seco. Delatava na organização desfibrada os rigores da fome e do combate. A magreza alongara-lhe o porte, ligeiramente curvo. A grenha, demasiadamente crescida, afogava-lhe a fronte estreita e fugitiva; e o rosto, onde o prognatismo se acentuara, desaparecia na lanugem espessa da barba, feito uma máscara amarrotada e imunda. Chegou em cambaleios. O passo claudicante e infirme, a cabeça lanzuda, a cara exígua, um nariz chato sobre lábios grossos, entreabertos pelos dentes oblíquos e saltados, os olhos pequeninos, luzindo vivamente dentro das órbitas profundas, os longos braços desnudos, oscilando - davam-lhe a aparência rebarbativa de um orango valetudinário.

Não transpôs a couceira da tenda.

Era um animal. Não valia a pena interrogá-lo

O general de brigada João da Silva Barbosa, da rede em que convalescia de ferimento recente, fez um gesto. Um cabo-de-esquadra, empregado na comissão de engenharia e famoso naquelas façanhas, 
adivinhou-lhe o intento Achegou-se com o braço. Diminuto na altura, entretanto, custou a enleá-lo ao pescoço do condenado. Este, porém, auxiliou-o tranquilamente; desceu o nó embaralhado; enfiou-o pelas próprias mãos, jugulando-se...

Perto, um tenente do estado-maior de primeira classe e um quintanista de medicina contemplavam aquela cena.

E viram transmudar-se o infeliz, apenas dados os primeiros passos para o suplício. Daquele arcabouço denegrido e repugnante, mal soerguido nas longas pernas murchas, despontaram, repentinamente, linhas admiráveis — terrivelmente esculturais — de uma plástica estupenda.

\section{Um primor de estatuária modelado em lama.}

Retificara-se de súbito a envergadura abatida do negro aprumandose, vertical e rígida, numa bela atitude singularmente altiva. A cabeça firmou-se-lhe sobre os ombros, que se retraíram dilatando o peito, alçada num gesto desafiador de sobranceria fidalga, e o olhar, num lampejo varonil, iluminou-lhe a fronte. Seguiu impassível e firme; mudo, a face imóvel, a musculatura gasta duramente em relevo sobre os ossos, num desempenho impecável, feito uma estátua, uma velha estátua de titã, soterrada havia quatro séculos aflorando, denegrida e mutilada, naquela imensa ruinaria de Canudos. Era uma inversão de papéis. Uma antinomia vergonhosa.

\section{E estas coisas não impressionavam...}

Fizera-se uma concessão ao gênero humano: não se trucidavam mulheres e crianças. Fazia mister, porém, que se não revelassem perigosas. Foi o caso de uma mamaluca quarentona, que apareceu certa vez, presa, na barraca do comandante-em-chefe. O general estava doente. Interrogou-a no seu leito de campanha - rodeado de grande número de oficiais. O inquérito resumia-se às perguntas do costume - acerca do número de combatentes, estado em que se achavam, recursos que possuíam, e outras, de ordinário respondidas por um "sei não!” decisivo ou um “e eu sei?" vacilante e ambíguo. A mulher, porém, desenvolta, enérgica e irritadiça, espraiou-se em considerações imprudentes. "Nada valiam tantas perguntas. Os que as faziam sabiam bem que estavam perdidos. Não eram sitiantes, eram presos. Não seriam capazes de voltar, como os das outras expedições; e em breve teriam desdita maior ficariam, todos, cegos e tateando à toa por aquelas colunas...” E tinha a gesticulação incorreta, desabrida e livre.

Irritou. Era um virago perigoso. Não merecia o bem-querer dos triunfadores. Ao sair da barraca, um alferes e algumas praças seguraram-na.

Aquela mulher, aquele demônio de anáguas, aquela bruxa agourentando a vitória próxima — foi degolada...

Poupavam-se as tímidas, em geral consideradas trambolhos incômodos no acampamento, atravessando-o, como bruacas imprestáveis.

Era o caso de uma velha que se aboletara com dois netos de cerca de dez anos junto à vertente em que acampava o piquete de cavalaria. Os pequenos, tolhiços, num definhamento absoluto, não andavam mais; tinham volvido a engatinhar. Choravam desapoderadamente, de fome. E a avó, desatinada, esmolando pelas tendas os restos das marmitas, e correndo logo a acalentá-los, aconchegando-lhes dos corpos os frangalhos das camisas; e deixando-os outra vez, agitante, infatigável no desvelo, andando aqui, ali, à cata de uma blusa velha, de uma bolacha caída do bolso dos soldados, ou de um pouco d'água; acurvada pelo sofrimento e pela idade, titubeando de um para outro lado, indo e vindo, cambeteante e sacudida sempre por uma tosse renitente, de tísica - constrangia os corações mais duros. Tinha o que quer que fosse de um castigo; passava e repassava como a sombra impertinente e recalcitrante de um remorso...

A degolação era, por isto, infinitamente mais prática, dizia-se nuamente. Aquilo não era uma campanha, era uma charqueada. Não era a ação severa das leis, era a vingança. Dente por dente. Naqueles ares pairava ainda, a poeira de Moreira César, queimado; devia-se queimar. Adiante, o arcabouço decapitado de Tamarindo; devia-se degolar. A repressão tinha dois pólos — o incêndio e a faca.

Justificavam-se: o coronel Carlos Teles poupara certa vez um sertanejo prisioneiro. A ferocidade dos sicários retraíra-se diante da alma generosa de um herói...

Mas este pagara o deslize imperdoável de ser bom. O jagunço, que salvara, conseguira fugir e dera-lhe o tiro que o removera do teatro da luta. Acreditava-se nestas coisas. Inventavam-nas. Eram antecipados recursos absolutórios. Exageravam-se, calculadamente, outras: os martírios dos 
amigos trucidados, caídos nas tocaias traiçoeiras, ludibriados depois de cadáveres e postos como espantalhos à orla dos caminhos... A selvageria impiedosa amparava-se à piedade pelos companheiros mortos Vestia o luto chinês da púrpura e, lavada em lágrimas, lavava-se em sangue.

\section{Um grito de protesto}

Ademais, não havia temer-se o juízo tremendo do futuro. A História não iria até ali.

Afeiçoara-se a ver a fisionomia temerosa dos povos na ruinaria majestosa das cidades vastas, na imponência soberana dos coliseus ciclópicos, nas gloriosas chacinas das batalhas clássicas e na selvatiqueza épica das grandes invasões. Nada tinha que ver naquele matadouro.

O sertão é o homízio. Quem lhe rompe as trilhas, ao divisar à beira da estrada a cruz sobre a cova do assassinado, não indaga do crime. Tira o chapéu, e passa.

E lá não chegaria, certo, a correção dos poderes constituídos. O atentado era público. Conhecia-o, em Monte Santo, o principal representante do governo, e silenciara. Coonestara-o com a indiferença culposa Desse modo a consciência da impunidade, do mesmo passo fortalecida pelo anonimato da culpa e pela cumplicidade tácita dos únicos que podiam reprimi-la, amalgamou-se a todos os rancores acumulados, e arrojou, armada até aos dentes, em cima da mísera sociedade sertaneja, a multidão criminosa e paga para matar.

Canudos tinha muito apropriadamente, em roda, uma cercadura de montanhas. Era um parêntese; era um hiato. Era um vácuo. Não existia. Transposto aquele cordão de serras, ninguém mais pecava.

Realizava-se um recuo prodigioso no tempo; um resvalar estonteador por alguns séculos abaixo.

Descidas as vertentes, em que se entalava aquela furna enorme, podia representar-se lá dentro, obscuramente, um drama sanguinolento da Idade das cavernas. O cenário era sugestivo. Os atores, de um e de outro lado, negros, caboclos, brancos e amarelos, traziam, intacta, nas faces, a caracterização indelével e multiforme das raças - e só podiam unificar-se sobre a base comum dos instintos inferiores e maus.

A animalidade primitiva, lentamente expungida pela civilização, ressurgiu, inteiriça. Desforrava-se afinal. Encontrou nas mãos, ao invés do machado de diorito e do arpão de osso, a espada e a carabina. Mas a faca relembrava-lhe melhor o antigo punhal de sílex lascado. Vibrou-a. Nada tinha a temer. Nem mesmo o juízo remoto do futuro.

Mas que entre os deslumbramentos do futuro caia, implacável e revolta; sem altitude, porque a deprime o assunto; brutalmente violenta, porque é um grito de protesto; sombria, porque reflete uma nódoa - esta página sem brilhos... 


\section{Capítulo III}

\section{Titãs contra moribundos}

O combate de 24 precipitara o desfecho. À compressão que se realizara ao norte, correspondeu, do mesmo modo vigoroso, outra, a 25, avançando do sul. O cerco constringia-se num apertão de tenaz. Entraram naquele dia em ação, descendo os pendores do Alto do Mário onde acampavam, num colo abrigado à retaguarda da Sete de Setembro, os dois batalhões do Pará e o $37^{\circ}$ de linha. E fizeram-no de moto próprio, alheios a qualquer ordem do comando geral.

Tinham motivos graves para aquele ato.

A derrocada de Canudos figurava-se-lhes iminente.

Da altura em que se abarracavam, no ângulo morto do boléu da vertente, examinavam-no a todo o instante; e viam arrochar-se embaixo a cintura do sítio; e ampliar-se, continuamente maior, a moldura lutuosa dos incêndios; e o povoado cada vez mais reduzido à grande praça deserta sempre, larga clareira onde por igual temiam penetrar os lutadores dos dois campos. Adiante, perto, estimulando-os, atroava o redente artilhado; embaixo, longe, crepitavam os tiroteios incessantes... e eles ali quedavam, inúteis, desdenhados pelas mesmas balas perdidas, que lhes zuniam por cima, muito altas, inofensivas.

De um momento para outro aquilo terminaria; e restar-lhes-ia a volta inglória - espadas virginalmente novas, bandeiras intactas sem o rendado precioso das batalhas. Porque o general-em-chefe não encobria o propósito de não precipitar os acontecimentos num dispêndio inútil de vidas, quando a rendição em poucos dias era inevitável. Este intento, expresso sem rodeios, sobre ser mais prático, era mais humano. Mas implicava o renome guerreiro por se fazer dos que não tinham ainda combatido. Desvairava-lhes a fama. Coagia-os ao constrangimento de receberem, grátis, as coroas antecipadamente bordadas nos Estados nativos pelas mães, pelas esposas ou pelas noivas e pelas irmãs saudosas. E não puderam conter-se. Desceram ruidosamente as vertentes.
Travaram então um combate que foi uma surpresa, menos para os atacados que para o resto das linhas sitiantes. Desencadeara-se para os lados do Cambaio, secundado pela artilharia do coronel Olímpio da Silveira e, a breve trecho, cresceu com extraordinária intensidade.

Ao que se propalou depois, aqueles heróis impacientes, dirigidos pelos coronéis Sotero de Meneses e Firmino Rego, levavam o objetivo de tomar o arraial. Carregariam até ao rio. Transpô-lo-iam batendo-se sem parar, numa arrancada. Romperiam pela praça vazia. Enfiariam, a marchemarche, numa dispersão de cargas de baionetas, por aqueles becos fora. Varrê-los-iam. Pulariam os entulhos fumegantes, apisoando os matutos atônitos. E iriam tombar — numa explosão de aplausos - sobre a tranqueira do norte, entre as guarnições surpreendidas e pasmas...

Era um golpe de audácia estupendo. Mas não conheciam os sertanejos. Estes tomaram-lhes vigorosamente o passo. Jarretaram-nos. Anularam-lhes, no fim de algum tempo, o intento. E vingaram-se sem o saberem. Porque havia, de feito, algo de dolorosamente insolente e irritante no afogo, na inquietação, na ânsia desapoderada, com que aqueles bravos militares - robustos, bem fardados, bem nutridos, bem armados, bem dispostos - procuravam morcegar a organização desfibrada de adversários que desviviam há três meses, famintos, baleados, queimados, dessangrados gota a gota, e as forças perdidas, e os ânimos frouxos, e as esperanças mortas, sucumbindo dia a dia num esgotamento absoluto. Dariam a última punctura de baioneta no peito do agonizante; o tiro de misericórdia no ouvido do fuzilado. E cobrariam, certo, pouca fama, com a façanha.

\section{Mas nem esta tiveram.}

Apertara-se mais o cerco, é certo, mas sem que o resultado atingido ressarcisse os sacrifícios feitos: cerca de oitenta homens fora de combate e entre eles, ferido o coronel Sotero, e morto o capitão Manuel Batista Cordeiro, do regimento do Pará.

\section{Constringe-se o assédio}

Em compensação, dizia-se, fora enorme a perda do inimigo centenares de mortos, centenares de casas conquistadas. Com efeito, a parte 
do arraial em poder daqueles reduzia-se agora a menos de terço — à orla setentrional da praça e casebres junto à igreja.

Onze batalhões $\left(16^{\circ}, 22^{\circ}, 24^{\circ}, 27^{\circ}, 32^{\circ}, 33^{\circ}, 37^{\circ}, 38^{\circ}\right.$, de linha, o do Amazonas, a ala direita do de S. Paulo, e o $2^{\circ}$ do Pará), mais de 2500 homens, tinham-se apoderado, nos últimos dias, de cerca de 2 mil casas e comprimiam os sertanejos, atirando-os de encontro à vertente da Fazenda Velha ao sul, e a leste contra igual número de baionetas dos $25^{\circ}, 7^{\circ}, 9^{\circ}, 35^{\circ}$, $40^{\circ}, 30^{\circ}, 12^{\circ}, 26^{\circ}$, de linha e $5^{\circ}$ de Polícia.

Eram 5 mil soldados, em números redondos, excluídos os que permaneciam de guarda ao acampamento e guarnecendo a estrada de Monte Santo.

A população combatida tinha, ao invés das linhas frouxas de um assédio largo, um círculo inteiriço de vinte batalhões, e amoitava-se em menos de quinhentos casebres, ao fundo da igreja, na última volta do rio. Os incêndios reduziam-lhe, além disto, hora por hora, o campo. E embora as casas, com o seu madeiramento escasso, pouco alimentassem as chamas, estas progrediam devagar, no abafamento das fumaradas pardacentas, lembrando a combustão imperfeita de centenares de fornos catalães - nos densos rolos de fumo afuliginando o firmamento, espraiando-se pelos tetos, tornando ainda mais tristonho o cenário desolado e monótono. A artilharia dos morros pouco atirava, exigindo as pontarias grandes resguardos porque o mínimo desvio ou variação das alças arrojaria as balas sobre os assaltantes.

Apesar disto, continuava inteiramente vazia a praça. Ninguém se abalançara ainda a tomar as casas que a limitavam pelo norte, perpendicularmente à latada; e dentro destas e das que se seguiam compactas, junto à igreja, se acolheram os últimos jagunços. Os mais afoitos guarneciam ainda os muramentos desmantelados do templo. Comandavam-nos chefes sem grande nomeada. Esses heróis anônimos, porém, dispuseram a sua gente para a morte e, voando a todos os pontos, alentavam resistência incompreensível, tomando todas as medidas que delongassem indefinidamente o desfecho.

Assim os lutadores, a partir de 26, se revezavam das trincheiras, de onde respondiam aos ataques, para outros misteres porventura mais pesados e sérios.

\section{Cavando o próprio túmulo}

Preparavam junto ao santuário o último reduto - uma escavação retangular e larga. Abriam o próprio túmulo. Batidos de todos os lados, iriam recuando, palmo a palmo, braço a braço, todos, para aquela cova onde se sepultariam, indomáveis.

Escavavam, buscando a água que lhes faltava, cacimbas profundas. As mulheres, e as crianças, e os velhos, e os enfermos, colaboravam nestes trabalhos brutos. Mal reprofundavam, porém, além de dois metros os estratos duríssimos, de modo a atingirem as camadas sobre que repousavam tênues lençóis, filtrados pelos últimos estagnados do rio. Alcançavam-nos, às vezes; para vê-los, uma hora depois extintos, sugados na avidez de esponja da atmosfera exsicada. E começou logo a torturá-los a sede, avivada pelas comoções e pela canícula queimosa. O combate fez-se-lhes, então, um divertimento lúgubre, uma atenuante a maiores misérias. Atiravam a esmo, sem o antigo rigor da pontaria, para toda a banda, num dispêndio de munições capaz de esgotar o arsenal mais rico. Os que se encurralavam na igreja nova continuavam varejando os altos, enquanto os demais tolhiam de frente, a dois passos, os batalhões entranhados no casario. Aí se realizavam episódios brutais. A apertura do campo e o estreito das bitesgas impropriando o movimento às seções mais diminutas davam à luta o traço exclusivo de uma bravura feroz. Alguns oficiais, ao avançarem, desapertavam os talins e jogavam a um lado a espada. Batiamse à faca.

Mas a empresa tornara-se, ao cabo, dificílima. A constrição do sítio condensara nas casas os que as defendiam e estes, enchendo-as, opunham resistência crescente. Quando cediam num ou noutro ponto, os vencedores tinham, ainda, inopinadas surpresas. A traça dos sertanejos colhia-os mesmo naquele transe doloroso.

\section{Trincheira de cadáveres}

Foi o que sucedeu ao ser conquistado um casebre, depois de tenazmente defendido. Os soldados invadiram-no atumultuadamente. E depararam um monte de cadáveres; seis ou oito, caídos uns sobre outros, abarreirando a entrada. Não se impressionaram com o quadro. Enveredaram 
pelos cômodos escuros. Mas receberam em cheio, pelas costas, partindo daquela pilha de trapos sanguinolentos, um tiro. Voltando-se, pasmos, detonou-lhes outro, à queima-roupa, de frente. Sopitando o espanto, comprimidos na saleta estreita, viram então saltar e fugir o lutador fantástico, que adotara o estratagema profanador, batendo-se por trás de uma trincheira de mortos...

\section{Em torno das cacimbas}

O lento avançar do assédio estacou, então, novamente. Imobilizava-o pela última vez o vencido. Ademais a situação não requeria maiores esforços. A vitória viria por si mesma. Bastava que se conservassem as posições. Fechadas todas as saídas e francamente batidas as cacimbas marginais do rio, o perdimento do arraial era inevitável, em dois dias no máximo - mesmo admitida a presunção de poderem os assediados, por tanto tempo e naqueles dias ardentes, suportar a sede que os flagelava.

Mas a resistência duraria uma semana ainda. Porque aquele círculo maciço de batalhões começou de ser partido, intermitentemente, pelos sertanejos, à noite.

Na de 26 houvera quatro ataques violentos; na de 27, dezoito; nas dos dias subsequentes, um único, porque já não intermitiram, prolongando-se, contínuos, das seis da tarde às cinco do amanhecer.

Não visavam rasgar um caminho à fuga. Empenhando-se todos ao sul atendiam à conquista momentânea das cacimbas, ou gânglios rebalsados do Vaza-Barris. Enquanto o grosso dos companheiros se batia, atraindo para o âmago do arraial a maior parte dos sitiantes, alguns valentes sem armas, carregando as borrachas vazias, aventuravam-se até à borda do rio. Avançavam cautelosamente. Abeiravam-se das poças esparsas e raras, que salpintavam o leito; e enchendo as vasilhas de couro volviam, correndo, arcados sob as cargas preciosas.

Ora, esta empresa, a princípio apenas difícil, foi-se tornando, a pouco e pouco, insuportável.

Descoberto o motivo único daqueles ataques, os sitiantes das posições ribeirinhas convergiam os fogos sobre as cacimbas, facilmente percebidas - breves placas líquidas rebrilhando ao luar ou joeirando, na treva, o brilho das estrelas...

De sorte que, atingindo-lhes as bordas, os sertanejos tinham, em torno e na frente, o chão varrido à bala.

Avançavam e caíam, às vezes, sucessivamente, todos.

Alguns antes que chegassem às ipueiras esgotadas, reduzidas a repugnantes lameiros; outros quando, de bruços, sugavam o líquido salobro e impuro; e outros quando, no termo da tarefa, volviam arcando sob os bogós repletos. Substituíam-nos outros, rompendo desesperadamente contra os tiroteios, afrontando-se com a morte. Ou, o que em geral sucedia, deixavam que se atreguasse a repulsa enérgica e mortífera e se descuidassem os soldados vigilantes. Mas estes, conhecendo-lhes os ardis, sabiam que tornariam outra vez em breve. Aguardavam-nos, pontarias imóveis, ouvidos armados ao menor ruído, olhos frechando, fitos, as sombras, como caçadores numa espera. E divisavam-nos, de fato, transcorridos minutos, indistintos, vultos diluídos no escuro, na barranca fronteira; e viam-nos, descendo lento e lento por ela abaixo, de bruços, rentes com o chão, vagarosamente, num rastejar serpejante de grandes sáurios silenciosos; e viam-nos depois, embaixo, arrastando-se pelo esteiro areento do rio...

Seguravam as pontarias. Deixavam-nos aproximar-se, e deixavamnos atingir os estagnados que eram o chamariz único daquela ceva monstruosa.

Então lampejava o fulgor das descargas subitâneas! Fulminavam-nos. Percebiam-se, adiante quinze metros, gritos dilacerantes de cólera e de dor; dois ou três corpos escabujando à beira das cacimbas; correndo outros, espavoridos; outros, feridos, em cambaleios; e outros desafiando o fuzilamento, pulando, sem resguardos agora, das barrancas - e velozes, terríveis, desafiadores - passando sobre os companheiros moribundos, arremetendo com a barreira infernal que os devorava.

Um único às vezes escapava, às carreiras. Transpunha a barranca de um salto, e perdia-se nos escombros do casario, levando aos companheiros alguns litros de água que custavam hecatombes. E era um líquido suspeito, contaminado de detritos orgânicos, de sabor detestável em que se pressentia 
o tóxico das ptomaínas e fosfatos dos cadáveres decompostos jazentes desde muito insepultos por toda aquela orla do Vaza-Barris.

Estes episódios culminaram o heroísmo dos matutos. Comoviam, por fim, aos próprios adversários.

\section{Sobre os muradais da igreja nova}

Não raro, quando toda a linha de sítio, ao norte, estrugia os ares em descargas compactas, sem que se distinguissem os tiros singulares, num ressoar intenso lembrando o de represas repentinamente abertas, e o bombardeio as completava, tombando dos morros - os combatentes da linha central do acampamento, arriscando-se aos projetis perdidos, borrifados pela refrega, faziam-se espectadores de uma cena extraordinária.

Em muitos despontou, ao cabo, irreprimível e sincero entusiasmo pelos valentes martirizados. Não o encobriam. O quadro que se lhes oferecia imortalizava os vencidos. Cada vez que os contemplavam, tinham, crescente, o assombro:

A igreja sinistra bojava, em relevo, sobre o casario em ruínas; e, impávidos ante as balas que sobre ela convergiam, viam-se, no resplendor fugaz das fuzilarias, deslizando-lhe pelas paredes e entulhos, subindo-lhe pelas torres derrocadas ou caindo por elas abaixo, de borco, presos aos blocos disjungidos, como titãs fulminados, vistos de relance num coriscar de raios, aqueles rudes patrícios indomáveis...

\section{Capítulo IV}

\section{Passeio dentro de Canudos}

Percebia-se-lhes, contudo, hora por hora, a exaustão.

Durante o dia o povoado, silencioso, marasmava na estagnação do bloqueio. Nem um ataque, às vezes. A 28 de setembro não replicaram às duas salvas de 21 tiros, de bala, com que foi criminosamente saudada, pela manhã e à tarde, a data belíssima que resume um dos episódios mais viris da nossa história. Era o fim.

Faziam-se já no acampamento preparativos para a volta; soavam livremente as cornetas; andava-se à vontade por toda a banda; entravam impunemente os comboios diários e correios, levando os últimos, para os lares distantes, as esperanças e as saudades dos triunfadores; grupos descuidados seguiam perlustrando pelas cercanias; improvisavam-se banquetes; e à tarde, formadas à frente dos quartéis de vários comandos, tocavam, nas retretas, as fanfarras dos corpos.

Percorria-se, ao cabo, quase todo o arraial.

A 29 o general-em-chefe e o comandante da $2^{\text {a }}$ coluna realizaram, com os estados-maiores respectivos, este passeio atraentíssimo.

Seguiram a princípio pelo alto das colinas à direita do acampamento e, depois de uma inflexão à esquerda descendo por dentro de sanga flexuosa, onde repontavam grandes placas de filades dando-lhe a feição de longa passagem coberta, avançaram até toparem as primeiras casas e, simultaneamente, esparsos, jazentes a esmo sobre montes de esteios, traves e ripas carbonizadas, os primeiros cadáveres insepultos do inimigo.

Tinha-se neste momento a impressão de uma entrada em velha necrópole que surgisse, desvendando-se de repente, à flor da terra. As ruínas agravavam a desordem das pequenas vivendas, construídas ao acaso, defrontando-se em bitesgas de um metro de largo, empachadas pelos tetos de argila abatidos. De sorte que a marcha se fazia adstrita a desvios tortuosos e longos. E a cada passo, passando junto aos casebres que ainda permaneciam de pé, oscilantes e arrombados, livres ainda das chamas, 
despontava ante o visitante atônito um traço pungente da vida angustiosa que se atravessara ali dentro.

Dizia-o, mais expressiva, a nudez dos cadáveres. Estavam em todas as posições, estendidos, de supino, face para os céus; desnudos os peitos, onde se viam os bentinhos prediletos; inflexos no último crispar da agonia; mal vistos, às vezes, caídos sob madeiramentos, ou de bruços sobre as trincheiras improvisadas, na atitude de combate em que os colhera a morte.

Em todos, nos corpos emagrecidos e nas vestes em pedaços, liam-se as provações sofridas. Alguns ardiam, lentamente, sem chamas, revelados por tênues fios de fumaça, que se alteavam em diversos pontos. Outros, incinerados, se desenhavam, salteadamente, nítidos, esbatida a brancura das cinzas no chão poento e pardo, à maneira de toscas e grandes caricaturas feitas a giz...

Seguia-se. A marcha gradativamente se tornava mais penosa, através de entulhos sucessivos de um esterquilínio pavoroso. A soldadesca varejando as casas pusera fora, às portas, entupindo os becos em monturos, toda a ciscalhagem de trastes em pedaços, de envolta com a farragem de molambos inclassificáveis: pequenos baús de cedro; bancos e jiraus grosseiros; redes em fiapos; berços de cipó e balaios de taquara; jacás sem fundo; roupas de algodão, de cor indefinível; vasilhames amassados, de ferro; caqueiradas de pratos, e xícaras, e garrafas; oratórios de todos os feitios; bruacas de couro cru; alpercatas imprestáveis; candeeiros amolgados, de azeite; canos estrondados, de trabucos; lascas de ferrões ou fueiros; caxerenguengues rombos...

E nestes acervos, nada, o mais simples objeto que não delatasse uma existência miseranda e primitiva. Pululavam rosários de toda a espécie, dos mais simples, de contas policrômicas de vidro, aos mais caprichosos, feitos de ouricuris; e, igualmente inúmeras, rocas e fusos, usança avoenga tenazmente conservada, como tantas outras, pelas mulheres sertanejas. Sobre tudo aquilo, incontáveis, esparsos pelo solo, apisoados, rasgados registros, cartas santas, benditos em caderninhos costurados, doutrinas cristãs velhíssimas, imagens amarfanhadas de santos milagreiros, verônicas encardidas, crucifixos partidos; e figas, e cruzes, e bentinhos imundos...

Em alguns lugares - um claro limpo, cuidadosamente varrido, um aceiro para que os incêndios não atingissem os entrincheiramentos. Varava- se mais facilmente por ali; penetrando fundo no casario e aproximando-se daqueles.

Topava-se, então, adiante, uma sentinela que recomendava em voz baixa prosseguir com cautela: o jagunço estava perto, menos de três metros, da outra banda da paliçada...

Os visitantes, generais, coronéis até ao último posto, na ansiedade de quem contorna uma emboscada, avançavam agachados, heroicamente cômicos, céleres, de cócaras, correndo. Transpunham a linha perigosa. Quebravam dois ou três becos. Chegavam a outra trincheira: soldados imóveis, espectantes, mudos ou conversando em cochichos. Reproduzia-se a mesma travessia com o coração e as pernas aos saltos, a mesma corrida ansiosa, até outra trincheira adiante: idênticos lutadores, cautos, silenciosos, estendidas ou enfiadas as carabinas pelos parapeitos, que os resguardavam.

Transcorridos quinhentos metros, volvia-se à esquerda deixando à retaguarda as Casas Vermelhas e tinha-se uma surpresa - uma rua, uma verdadeira rua, a do Monte Alegre, a única que merecia tal nome, alinhada, larga de uns três metros e alongando-se de norte a sul, até à praça, cortando todo o arraial. Nela se erigiam as melhores vivendas, algumas casas de telhas e soalho, e entre estas a de Antônio Vila-Nova, onde dias antes se tinham encontrado restos de munições da coluna Moreira César.

Descia-se por ela em suave declive, divisando-se no extremo, na praça, um lanço derruído da igreja. Mas a breve trecho estacava-se de encontro a outro entrincheiramento, onde se adensava maior número de combatentes. Era o último, naquele rumo. Dali por diante um passo mais era o espingardeamento certo. Toda a parte do arraial à direita e na frente estava ainda em poder dos habitantes. Os adversários acotovelavam-se. Ouvia-se, transudando das paredes de taipa, o surdo e indefinível arruído da população entocada: vozes precípites, cautas, segredando sob o abafamento dos colmos; arrastamentos de móveis; soar de passos; e uns como longínquos clamores e gemidos; e às vezes — notas cruelmente dramáticas! — gritos, e choros, e risos, de crianças...

Volvia-se dali para a esquerda, voltando ao ponto de partida, através das casas tomadas nas vésperas, e o passeio tornava-se amedrontador. Em todo este novo segmento da linha do sítio, definindo-lhe o avançamento máximo depois dos combates da última semana, não se tinham destruído os 
casebres. Derrubadas apenas as paredes interiores e as empenas, as coberturas de barro sucediam-se unidas ou pouco espaçadas, feito o teto de longuíssimo armazém abarracado. A barreira de esteios e vigas, canastras e trastes de toda a sorte, por detrás da qual se alinhavam os batalhões, progredia por ela dentro, torcida e longa, desaparecendo de todo numa distancia de trinta metros, perdida na penumbra. Adivinhavam-se os soldados, a um lado, guarnecendo-a. Pelos recantos escuros, à retaguarda, lobrigavam-se os corpos dos jagunços mortos nos últimos dias, que fora perigoso queimar entre acervos de farrapos e estilhas de madeira, esparsos por toda a parte.

\section{Impregnava o ambiente um bafio angulhento de caverna.}

Era preciso valor para atravessar aquela espécie de túnel, em cuja boca, ao longe, mal se divisava um reflexo pálido do dia. Porque, a dois passos, ladeando-o, paralelamente, se estendia o entrincheiramento invisível do inimigo, interpostas as paredes fronteiras, enfrestadas. De sorte que o mínimo descuido, o mais rápido olhar por cima daqueles parapeitos de ciscalhos, era duramente pago. É que de parte a parte estavam as mesmas astúcias, avivadas dos mesmos ódios. Naquele sombrio finalizar da luta os antagonistas temiam-se por igual. Evitavam por igual o recontro franco. Negaceavam, estadeando as mesmas ardilezas e a mesma proditória quietitude. Imóveis largo tempo, um em frente ao outro, abrigados na mesma sombra, parecendo refletir a adinamia do mesmo esgotamento espiavam-se, solertes, traiçoeiros, tocaiando-se. E não podiam encontrar melhor cenário para ostentarem ambos, soldados e jagunços, a forma mais repugnante do heroísmo do que aquele esterquilínio de cadáveres e trapos, imersos na obscuridade de uma furna.

Seguia-se por ali envolto de um silêncio lúgubre. Percebiam-se os soldados esfrangalhados, imundos, sem bonés, sem fardas, cobertos de chapéus de couro ou de palha, calçando alpercatas velhas, vestidos com o mesmo uniforme do adversário. E acreditava-se que, com alguma presença de espírito, o sertanejo pudesse insinuar-se pelos rombos do tapume extenso, e aparecer entre eles, e achegar-se com a espingarda ao parapeito, e ali se quedar forrando-se às torturas do cerco, sem que o conhecessem - o que ademais era facilitado pela mistura dos diversos batalhões. Nem o atraiçoaria palmar ignorância dos deveres ou exigências da vida militar, porque esta se extinguira, por completo. Não havia revistas, formaturas, nem toques, nem vozes de comando. Distribuídos os cartuchos, cada um se encostava ao espaldão de cacaréus pronto ao que desse e viesse.

Distribuídas as rações diárias, fartas agora, cada um as preparava quando se lhe antojava ensejo. Aqui, ali, à retaguarda da linha ou dentro dos cubículos estreitos, sobre trempes de adobes ou pedras, chiavam as chaleiras aquentando água para o café; ferviam panelas; destacavam-se grandes quartos de boi, pendurados aos caibros, avermelhando no escuro, sobre braseiros, assando. Em torno, acocorados, carabinas sobraçadas, viam-se, em grupo, os combatentes que aproveitavam ligeira trégua para almoçar ou jantar. Dali corriam, não raro, em tumulto, jogando fora os canecos de jacuba ou nacos de churrasco precipitando-se para a estacada quando, de súbito, estalava um tiro adiante e zuniam logo as balas esfuziantes, varando os tetos, estilhaçando ripas e traves, esbotenando paredes, emborcando caldeirões - espalhando soldados como um pé de vento sobre palhas. No parapeito, adiante, replicavam de pronto os que já lá estavam, atirando a esmo contra o tabique que defrontavam e donde partira a agressão. Imitavam-nos os companheiros laterais. Logo depois vibrava um abalo nervoso, único, estendendo-se daquele ponto aos dois extremos, com uma trepidação vibrátil de descargas; e travava-se o combate, de improviso, furiosamente, desordenadamente, entre adversários que se não viam...

Baqueavam algumas praças, mortas ou feridas. Conquistavam-se dois ou três casebres mais - empurrando-se logo por diante toda a cangalhada de móveis, encurvando-se a tranqueira num ângulo saliente em talhante avançado. Volviam, prestes, os lutadores que mais se tinham avantajado, às posições primitivas. E o silêncio descia de novo, reinando outra vez o mesmo silêncio formidável: soldados mudos e imóveis, acaroados com a borda da tapada sinistra, espectantes, na tocaia; ou, ao fundo, em roda dos brasidos, reatando as merendas ligeiras, que tinham, às vezes, uns trágicos convivas — os moradores assassinados, estirados pelos recantos...

Deixava-se, por fim, este segmento sinistro do bloqueio, que trancava quase todo o quadrante do norte. Prosseguia-se, a céu aberto agora, em pleno dia, atravessando quintalejos pobres de cercas caídas e canteiros rasos, sem mais uma flor, e atravancados da mesma ciscalhagem indefinível, em montes. Sobre estes, corpos de sacrificados ainda: pernas surdindo inteiriçadas; braços repontando desnudos, num retesamento de 
angústia; mãos espalmadas e rígidas, mãos contorcidas em crispaduras de garras, apodrecendo, sinistras, em gestos tremendos de ameaça ou apelos excruciantes...

Deparavam-se novos viventes: gozos magríssimos, famélicos lebréus, pelados, esvurmando lepra, farejando e respirando aqueles monturos, numa ânsia de chacais, devorando talvez os próprios donos. Fugiam rápidos. Alguns cães de fila, porém, grandes molossos ossudos e ferozes, afastavamse devagar, em rosnaduras ameaçadoras, adivinhando no visitante o inimigo, o intruso irritante e mau.

Ia-se descendo sempre, até à sanga escavada, embaixo, correndo, em direção perpendicular à que se levava, para o Vaza-Barris ao longe, para onde canalizavam, nas quadras chuvosas, as águas das vertentes interopostas. Ali terminava, batendo contra o topo da colina, onde estava a comissão de engenharia, a parte do arraial expugnada a 18 de julho. Podia atingir-se diretamente o acampamento seguindo em frente, transpondo o valo, subindo e atravessando, à meia encosta, a bateria de Krupps emparcada ao fundo do quartel-general da $1^{\mathrm{a}}$ coluna; ou, num desvio longo, volvendo à direita, acompanhando o valo, perlongando a linha primitiva do assédio, descendo para o sul. A travessia era sem riscos. As casas - num desordenado arruamento às bordas daquele sulco de erosão, acompanhandolhe o declive, caindo-lhe pelos ressaltos, envesgando-lhe pelas curvas vivas - tinham, na maioria, sido desmanchadas, salvante poucas, as melhores, onde se improvisavam salas de ordem das brigadas, quartéis e ranchos da oficialidade. Uma delas era digna de nota. Fora uma tenda de ferreiro. Mostravam-no ainda alguns gastos marrões, tenazes partidas e derruída forja fixa, de adobes. E aquela ferraria, pobre do sertão, tinha uma bigorna luxuosa, do mais fino aço, que se fundira em Essen: um dos canhões tomados à expedição Moreira César.

Continuando a marcha topava-se a "linha negra", nome que primitivos sucessos justificavam, mas agora inexplicável para quem vinha das sombrias trincheiras deixadas ao norte.

Seguia-se acompanhando-a pelo fundo de um fosso, até se abrir a meio caminho, à direita, um claro amplo - a praça das igrejas, deserta, achanada, varrida, fazendo avultar maior, mais dominador, mais brutal, mais sinistro, com os seus paredões incumbentes, fendidos de alto a baixo, com a sua fachada estupenda esboroando em monólitos, com as suas torres roídas, e o adro entupido de blocos encaliçados, e a nave, lá dentro, vazia, escura, misteriosa - o templo monstruoso dos jagunços.

Dados mais alguns passos fronteava-se a igreja velha, inteiramente queimada, reduzida às quatro paredes exteriores.

Tinham-se nesse momento, à esquerda, o mais miserando dos campos santos, centenares de cruzes — dois paus roliços amarrados com cipós - fincados sobre sepulturas rasas.

Transpunha-se depois o Vaza-Barris; enfiava-se pelo sulco profundo do Rio da Providência, percorrendo, em torcicolos, as fileiras dizimadas do $5^{\circ}$ de Polícia, reduzido ao terço do primitivo quadro - e chegava-se, no tombador da Favela, a uma clareira em declive. No alto o baluarte Sete de Setembro sobressaía em balcão, dominante.

Percorria-se rapidamente aquele intervalo perigoso, alcançando-o.

Contemplava-se o arraial embaixo. Modificara-se, afinal, o aspecto - sombreado de largas manchas escurentas, de incêndios; erriçado de madeiramentos varando pelos rombos dos tetos; tumultuando em montões de argila — num esmagamento completo, arruinado, queimado, devastado...

Apenas estreita fímbria da face norte da praça e o núcleo de casebres junto à latada e à retaguarda da igreja se figuravam intactos. Mas eram em número diminuto, quatrocentos talvez, comprimidos em área reduzida. E os que neles se abrigavam certo não suportariam por uma hora um assalto de 6 mil homens.

Valia a pena tentá-lo. 


\section{Capítulo V}

\section{O assalto}

Foi o que fez o comando-em-chefe, contravindo ao propósito de aguardar a rendição sem dispêndio inútil de vidas, pelo enfraquecimento contínuo dos rebeldes.

Reunidos a 30 de setembro os principais chefes militares, concertaram nos dispositivos do recontro para o dia imediato. E, de acordo com os lineamentos do plano adotado, naquele mesmo dia à noite mobilizaram-se as unidades do combate, ocupando, assim, de véspera, as posições para a investida ${ }^{1}$.

$\mathrm{O}$ assalto seria iniciado por duas brigadas, a $3^{\mathrm{a}}$ e $6^{\mathrm{a}}$, dos coronéis Dantas Barreto e João César Sampaio, a primeira endurada por três meses de contínuos recontros e a última, recém-vinda, de combatentes que ansiavam a medir-se com os jagunços. Aquela deixou, então, a sua antiga posição na linha negra, sendo substituída por três batalhões, $9^{\circ}, 22^{\circ}$ e $34^{\circ}$, e, contramarchando para a direita, seguiu rumo à Fazenda Velha, de onde juntamente com a outra, formada dos $29^{\circ}, 39^{\circ}$ e $4^{\circ}$ Batalhões, se moveu até estacionar à retaguarda e flancos da igreja nova, objetivo central do acometimento.

Completariam este movimento primordial outros, secundários e supletivos: no momento da carga, o $26^{\circ}$ de Linha, o $5^{\circ}$ da Bahia e ala direita do Batalhão de S. Paulo, tomariam rapidamente posições junto à barranca esquerda do Vaza-Barris, à ourela da praça, onde se conservariam até nova ordem. À sua retaguarda se estenderiam em apoio os dois corpos do Pará, prontos a substituírem-nos, ou a reforçarem-nos, segundo as eventualidades do combate. De sorte que este, iniciado à retaguarda e aos flancos da igreja, iria a pouco e pouco, deslocando-se para a linha de baionetas que se cosia à barranca lateral do rio, na face sul da praça.

Era, como se vê, um arrochar vigoroso - em que colaborariam os demais corpos guarnecendo as posições recém-conquistadas e o acampamento. Interviriam na ação à medida das circunstâncias, ou quando tombassem diante das trincheiras e das barrancas as chusmas de inimigos repulsados.

Sobre tudo isto - preliminar preparatória e indispensável - um bombardeio firme, em que entrariam todos os canhões do sítio, batendo por espaço de uma hora a estreita área a expugnar-se. Somente depois que eles emudecessem, arremeteriam as brigadas assaltantes, de baionetas caladas, sem fazerem fogo, salvo se o exigissem as circunstâncias. Em tal caso, porém, devia ser feito na direção única da meridiana, a fim de não serem atingidos os batalhões jazentes nas posições próximas ao conflito. A $3^{\mathrm{a}}$ Brigada, ao toque geral partido do comando-em-chefe, de "infantaria avançar!”, seguiria a marche-marche, procurando o flanco esquerdo da igreja, junto ao qual se estenderia distante cento e cinquenta metros; enquanto dois batalhões da $6^{\mathrm{a}}$, o $29^{\circ}$ e o $39^{\circ}$, investissem para a retaguarda daquela, e o $4^{\circ}$, transpondo também o Vaza-Barris, a acometesse pelo flanco direito. Os demais combatentes seriam, a não ser que o imprevisto determinasse ulteriores combinações, simples espectadores da ação.

\section{O canhoneio}

E no amanhecer do $1^{\circ}$ de outubro começou o canhoneio.

Convergia sobre o núcleo reduzido dos últimos casebres, partindo de longo semicírculo de dois quilômetros, das baterias próximas ao acampamento até ao redente extremo, da outra banda, onde findava a estrada do Cambaio. Durou 48 minutos apenas, mas foi esmagador. As pontarias estavam feitas de véspera. Não havia errar o alvo imóvel.

Dava-se, além disto, a última lição à rebeldia impenitente. Era preciso que, francamente desbravado o chão para o assalto, não sobreviessem mais surpresas dolorosas e ele se executasse, de pronto, fulminante e implacável, com os entraves únicos de um passo de cargas sobre ruínas. Fizeram-se as ruínas.

Via-se a transmutação do trecho torturado: tetos em desabamentos, prensando, certo, os que se lhes acolhiam por baixo, nos cômodos estreitos; tabiques esboroando, voando em estilhas e terrões; e aqui e ali, em começo 
dispersos e logo depois ligando rapidamente, sarjando de flamas a poeira dos escombros, novos incêndios, de súbito deflagrando.

Por cima - toldada a manhã luminosa dos sertões — uma rede vibrante de parábolas..

Não havia perder-se uma granada única. Batiam nas cimalhas rotas das igrejas, explodindo em estilhas, ou saltando em ricochetes largos, para diante, sobre o santuário e a latada; arrebentavam nos ares; arrebentavam sobre a praça; arrebentavam sobre os colmos, esfarelando as coberturas de barro; entravam, arrebentando, pelos colmos dentro; basculhavam os becos enredados, revolvendo-lhes os ciscalhos; e revolviam, de ponta a ponta, inflexivelmente, batendo-o casa por casa, o último segmento de Canudos. Não havia anteparos ou pontos desenfiados, que o resguardassem. O abrigo de um ângulo morto formado pelos muros da igreja nova, antepostos aos disparos da Sete de Setembro, era inteiramente destruído pelas trajetórias das baterias de leste e oeste. Os últimos jagunços tinham, intacta, fulminando-os, sem perda de uma esquírola de ferro, toda a virulência daquele bombardeio impiedoso.

Entretanto não se notou um grito irreprimível de dor, um vulto qualquer fugindo, ou a agitação mais breve. E quando se deu o último disparo, e cessou o fragor dos estampidos, a inexplicável quietude do casario fulminado fazia supor o arraial deserto, como se durante a noite a população houvesse, miraculosamente, fugido.

Houve um breve silêncio. Vibrou um clarim no alto da Fazenda Velha. Principiou o assalto.

Consoante as disposições anteriores, os batalhões abalaram convergentes de três pontos, sobre a igreja nova. Seguiram, invisíveis, entre os casebres ou pelo talvegue do Vaza-Barris. Um único, pela direção que trilhava, se destacou à contemplação do resto dos combatentes, o $4^{\circ}$ de Infantaria. Viram-no atravessar a marche-marche, de armas suspensas, o rio; transpô-lo; galgar a barranca; aparecer, alinhado e firme, à entrada da praça.

Era a primeira vez que ali chegavam lutadores numa atitude corretamente militar.

\section{Réplica dos jagunços}

Feito este movimento, aquele corpo marchou heroicamente, avançando. Mas desarticulou-se, dados alguns passos, num desequilíbrio instantâneo. Baquearam alguns soldados, de bruços, como se se preparassem para atirar melhor por trás dos blocos da fachada destruída; viam-se outros, recuando, fora da forma; distanciaram-se, arremetendo para a frente, outros; depois um enredado de baionetas entrebatendo-se, em grupos dispersos - erradios. E logo após, pelos ares ainda silenciosos, um estouro, lembrando arrebentamento de minas...

O jagunço despertava, como sempre, de improviso, surpreendedoramente, teatralmente e gloriosamente, renteando o passo aos agressores.

Estacou o $4^{\circ}$, batido de chapa pelos adversários emboscados à ourela da praça; estacaram o $39^{\circ}$ e o $29^{\circ}$, ante descargas à queima-roupa, através das paredes ao fundo do santuário; e, pela sua esquerda, imobilizou-se a carga da Brigada Dantas Barreto. Fortemente atacada por um dos flancos, esta teve que avançar naquele sentido, abandonando a direção inicial da investida, o que foi imperfeitamente conseguido por três companhias dispersas, destacadas do grosso dos batalhões.

Modificavam-se todos os movimentos táticos preestabelecidos. Ao invés da convergência sobre a igreja, as brigadas paravam ou fracionavamse embitesgando nas vielas.

Durante cerca de uma hora os combatentes que contemplavam a refrega, no alto das colinas circunjacentes, nada mais distinguiram, fora da assonância crescente dos estampidos e brados longínquos - arruído confuso de onde expluíam, constantes, sucessivos, quase angustiosos, abafados clangores de cornetas. Desapareceram as duas brigadas, embebidas de todo na casaria indistinta. Mas contra o que era de esperar, os sertanejos permaneceram invisíveis e nem um só apareceu, correndo para a praça. Batidos entretanto, por três lados, deviam, recuando por ali e precipitando-se na fuga, ir de encontro às baionetas das forças estacionadas nas linhas centrais e nas beiradas do rio. Era este, como vimos, o objetivo primordial do assalto. Falhou completamente. E o malogro valia por um revés. Porque os assaltantes, deparando resistências com que não contavam, 
paravam, entrincheiravam-se; e assumiam atitude de todo contraposta à missão que levavam. Quedaram na defensiva franca. Caíam-lhes em cima, desbordando os casebres fumegantes e assaltando-os, os jagunços.

Apenas a igreja nova fora tomada e dentro da sua nave revolvida os soldados do $4^{\circ}$, trepados em montões de blocos e caliça, embaralhavam-se, em tumulto, com os das companhias pertencentes à $3^{\mathrm{a}}$ Brigada. Este sucesso, porém, verificara-se inútil. A um lado, estrepitava, feroz, contínua, ensurdecedora, a trabucada dos guerrilheiros, que enchiam o santuário.

E a praça, onde devia aparecer o inimigo repelido, ferretoado à baioneta, permanecia deserta.

Era urgente ampliar o plano primitivo do ataque, lançando no conflito novos lutadores. Do alto da Sete de Setembro partiu o sinal do comando-em-chefe, e logo depois o toque de avançar para o $5^{\circ}$ da Bahia. Lançava-se o jagunço contra o jagunço.

O batalhão de sertanejos avançou. Não foi a investida militar, cadente, derivando a marche-marche, num ritmo seguro. Viu-se um como serpear rapidíssimo de baionetas ondulantes, desdobradas, de chofre, numa deflagração luminosa, traçando em segundos uma listra de lampejos desde o leito do rio até aos muros da igreja...

O mesmo avançar dos jagunços, célere, estonteador, escapante à trajetória retilínea, num colear indescritível. Não foi uma carga, foi um bote. Em momentos uma linha flexível, de aço, enleou o baluarte sagrado do inimigo. Coruscou um relâmpago de duzentas baionetas: o $5^{\circ}$ desapareceu mergulhando nos escombros...

Mas a situação não mudou. Aquele fragmento revolto do arraial, para cuja expugnação pareciam excessivas duas brigadas, absorvera-as; absorvera o reforço enviado; ia absolver batalhões inteiros. Seguiram, logo depois, o $34^{\circ}$, o $40^{\circ}$, o $30^{\circ}$ e o $31^{\circ}$ de Infantaria. Duplicavam as forças assaltantes. Aumentou, num crescendo, o estrépito da batalha invisível; ampliaram-se os incêndios; ardeu toda a latada. Mas na espessa afumadura dos ares embruscados branqueava, embaixo, a praça absolutamente vazia.

\section{Baixas}

Ao fim de três horas de combate, tinham-se mobilizado 2 mil homens sem efeito algum. As nossas baixas avultavam. Além de grande número de praças e oficiais de menor patente, baquearam mortos, logo pela manhã, o comandante do $29^{\circ}$, major Queirós, e o da $5^{\mathrm{a}}$ Brigada, tenente-coronel Tupi Ferreira Caldas.

\section{Tupi Caldas}

A deste originara raro lance de bravura. Os soldados do $30^{\circ}$ idolatravam-no. Era uma rara vocação militar. Irrequieto, nervoso e impulsivo, o seu temperamento casava-se bem à vertigem das cargas e à rudeza das casernas. Nesta campanha mesmo jogara várias vezes a vida. Fora o comandante da vanguarda a 18 de julho; e depois daquele dia saíra indene dos mais mortíferos tiroteios. As balas tinham-no até então poupado, arranhando-o, rendando-lhe o chapéu, amolgando-lhe a chapa do talim. A última fulminou-o. Entrou por um dos braços, soerguido para sustentar o binóculo com que contemplava o assalto, e traspassou-lhe o peito. Atirou-o em terra, instantaneamente, morto. O $30^{\circ}$ procurou vingá-lo. Correu-lhe pelas fileiras um frêmito de pavor e de cólera, e depois transmontou de um pulo a tranqueira em que se abrigava. Embateu contra os casebres entrincheirados, de onde partira o projétil e arrojou-se a marche-marche, envesgando por uma viela em torcicolos. Não se ouviu um tiro. Soldados alvejados à queima-roupa caíam por terra rugindo enquanto os companheiros lhes passavam por cima esbarrando contra as portas, arrombando-as a coronhadas, penetrando os cômodos escuros, travando-se, lá dentro, em pugilatos corpo a corpo.

Esta arremetida, porém, das mais temerárias que se fizeram em todo o decorrer da luta, como as demais, reduziu-se ao primeiro ímpeto. Sopeoua a tenacidade incoercível dos jagunços. O $30^{\circ}$, consideravelmente desfalcado, refluiu em desordem à posição primitiva.

Por toda a banda realizavam-se idênticos arremessos e idênticos recuos. O último estortegar dos vencidos quebrava a musculatura de ferro das brigadas. 
Entretanto, pouco antes de nove horas, alentou-as a ilusão arrebatadora da vitória. Ao avançar um dos batalhões de reforço, um cadete do $7^{\circ}$ cravara nas junturas das paredes estaladas da igreja a bandeira nacional. Ressoaram dezenas de cornetas e um viva à República saltou, retumbando, de milhares de peitos. Surpreendidos com o inopinado da manifestação, os sertanejos amorteceram e cessaram o tiroteio. E a praça, pela primeira vez, desbordou de combatentes. Muitos espectadores desceram, rápidos, as encostas. Desceram os três generais. Ao passarem pela baixada da linha negra, viram às encontroadas entre quatro praças, dois jagunços presos. Adiante e aos lados - agitando os chapéus, agitando as espadas e as espingardas, cruzando-se, correndo, esbarrando-se, abraçandose, torvelinhando pelo largo - combatentes de todos os postos em delírios de brados e ovações estrepitosas.

\section{Terminara afinal a luta crudelíssima...}

Mas os generais seguiam com dificuldades, rompendo pela massa tumultuária e ruidosa, na direção da latada, quando, ao atingirem grande depósito de cal que a defrontava, perceberam surpreendidos, sobre as cabeças, zimbrando rijamente os ares, as balas...

O combate continuava. Esvaziou-se, de repente, a praça.

Foi uma vassourada.

\section{A dinamite}

E volvendo de improviso às trincheiras, volvendo em corridas para os pontos abrigados, agachados em todos os anteparos, esgueirando-se cosidos às barrancas protetoras do rio, retransidos de espanto, tragando amargos desapontamentos, singularmente menoscabados na iminência do triunfo, chasqueados em pleno agonizar dos vencidos — os triunfadores, aqueles triunfadores, os mais originais entre todos os triunfadores memorados pela História, compreenderam que naquele andar acabaria por devorá-los, um a um, o último reduto combatido. Não lhes bastavam 6 mil Mannlichers e 6 mil sabres; e o golpear de 12 mil braços, e o acalcanhar de 12 mil coturnos; e 6 mil revóveres; e vinte canhões, e milhares de granadas, e milhares de shrapnels; e os degolamentos, e os incêndios, e a fome, e a sede; e dez meses de combates, e cem dias de canhoneio contínuo; e o esmagamento das ruínas; e o quadro indefinível dos templos derrocados; e, por fim, na ciscalhagem das imagens rotas, dos altares abatidos, dos santos em pedaços - sob a impassibilidade dos céus tranquilos e claros - a queda de um ideal ardente, a extinção absoluta de uma crença consoladora e forte...

Impunham-se outras medidas. Ao adversário irresignável as forças máximas da natureza, engenhadas à destruição e aos estragos. Tinham-nas, previdentes. Havia-se previsto aquele epílogo assombroso do drama. Um tenente, ajudante de ordens do comandante geral, fez conduzir do acampamento dezenas de bombas de dinamite. Era justo; era absolutamente imprescindível. Os sertanejos invertiam toda a psicologia da guerra: enrijavam-nos os reveses, robustecia-os a fome, empedernia-os a derrota.

Ademais entalhava-se o cerne de uma nacionalidade.

Atacava-se a fundo a rocha viva da nossa raça. Vinha de molde a dinamite... Era uma consagração.

Cessaram as fuzilarias; e desceu sobre todas as linhas um grande silêncio de expectativa ansiosa... Logo depois correu um frêmito pela cercadura do sítio; espraiou-se pela periferia dilatada; passou, vibrátil, pelo acampamento; passou, num súbito estremeção, pelas baterias dos morros; e avassalou a redondeza, num trêmulo vibrante de curvas sismais cruzando-se pelo solo. Tombaram os dentilhões despegados das igrejas; desaprumaramse paredes, caindo; voaram tetos e tetos; tufou um cumulus de poeira espessando a afumadura dos ares; e, dentre centenares de exclamações irreprimidas, de espanto, retumbou a atroada de explosões fortíssimas. Parecia tudo acabado. O último trecho de Canudos arrebentava todo.

Os batalhões, embolados pelos becos, fora da zona mortífera das traves e cumeeiras que zuniam, em estilhas, sulcando para toda a banda o espaço, aguardavam que se diluísse aquele bulcão de chamas e pó, para o derradeiro acometimento.

Mas não o executaram. Houve ao contrário um recuo repentino. Batidos de descargas que não se compreendia como eram feitas daqueles braseiros e entulhos, os assaltantes acobertaram-se em todas as esquinas, esgueiraram-se pelas abas dos casebres e pularam, na maioria, para trás dos entrincheiramentos. 
Adiante atordoava-os assonância indescritível de gritos, lamentos, choros e imprecações, refletindo do mesmo passo o espanto, a dor, o exaspero e a cólera da multidão turturada que rugia e chorava. Via-se indistinto entre lumaréus um convulsivo pervagar de sombras: mulheres fugindo dos habitáculos em fogo, carregando ou arrastando crianças e entranhando-se, às carreiras, no mais fundo do casario; vultos desorientados, fugindo ao acaso para toda a banda; vultos escabujando por terra, vestes presas das chamas, ardendo; corpos esturrados, estorcidos, sob tições fumarentos... E, dominantes, sobre este cenário estupendo, esparsos, sem cuidarem de ocultar-se, saltando sobre os braseiros e aprumando-se sobre os colmos ainda erguidos, os últimos defensores do arraial. Ouviamse as suas apóstrofes rudes, distinguiam-se vagamente os seus perfis revoluteando por dentro da fumarada; e por toda a parte, salteadamente, a dois passos das linhas de fogo, aparecendo, improvisas, fisionomias sinistras, laivadas de mascarras, bustos desnudos chamuscados, escoriados, embatendo-as, em assaltos temerários e doidos...

\section{Continua a réplica}

Vinham matar os adversários sobre as próprias trincheiras. Estes esmoreciam. Verificaram a inanidade do bombardeio, das cargas repetidas e do recurso extremo da dinamite. Desanimavam. Perderam a unidade de ação e do comando. Os toques das cornetas contrabatiam-se, discordes, interferentes nos ares, sem que ninguém os entendesse. Não havia obedecêlos, variando as condições táticas a cada minuto e a cada passo. As seções de uma mesma companhia avançavam, recuavam ou imobilizavam-se; subdividiam-se em todas as esquinas; misturavam-se com as de outros corpos; embatiam com as casas ou contornavam-nas, ou dispersavam-se aliando-se a outros grupos e reeditando, dados alguns passos, as mesmas avançadas e os mesmos recuos, e a mesma dispersão. De sorte que, por fim, se agitavam em bandos desorientados, em que se amalgamavam praças de todos os batalhões.

\section{Baixas}

Aproveitando este tumulto, os jagunços fuzilaram-nos a salvo e sem piedade. A breve trecho os combatentes, que não tinham o anteparo dos espaldões, acumularam-se às abas das vivendas ainda intactas, ou alongaram-se, distanciados, pelos becos da parte conquistada - evitando a zona perigosa. Esta, porém, alastrava-se. Baqueavam combatentes para além das trincheiras; caíam inteiramente fora da órbita flamejante do combate e, como nos maus dias da primeira semana do assédio, a mínima imprevidência e o mais rápido afastamento daqueles abrigos frágeis eram uma temeridade.

O capitão-secretário do comando da $2^{\mathrm{a}}$ coluna, Aguiar e Silva, quando lhe passava por perto um pelotão em marcha, retirou-se por um instante do cunhal que o acobertava e, para animar o ataque, tirou entusiasticamente o chapéu, levantando um viva à República. Mas não pronunciou as últimas sílabas. Varou-o uma bala, em pleno peito, derrubando-o.

O comandante do $25^{\circ}$, major Henrique Severino, teve idêntico destino. Era uma alma belíssima, de valente. Viu em plena refrega uma criança a debater-se entre as chamas. Afrontou-se com o incêndio. Tomou-a nos braços; aconchegou-a do peito - criando com um belo gesto carinhoso o único traço de heroísmo que houve naquela jornada feroz - e salvou-a. depois.

Mas expusera-se. Baqueou, malferido, falecendo poucas horas

E assim por diante. O combate transformara-se em tortura inaturável para os dois antagonistas.

\section{No hospital de sangue}

As nossas baixas avultavam. Os espectadores, atestando os mirantes acasamatados da coluna extrema do acampamento, avaliavam-nas pela lúgubre procissão de andores, padiolas e redes que lhes passava de permeio, subindo. Saía da sanga, embaixo; derivava vagarosa na ascensão contorneando em desvios as casas por ali espalhadas; galgava o alto e prosseguia, descendo para o hospital de sangue, onde, à uma hora da tarde, já haviam chegado cerca de trezentos feridos.

Mas aquela alpendrada de couro, cobrindo a reentrância que se abrigava entre colinas, não os continha. Os feridos entulhavam-na; desbordavam para as abas das encostas envolventes, ao sol, sobre as pedras; 
e arrastavam-se, disputando a sombra das barrancas, até à farmácia anexa e pavilhão dos médicos, por onde se cruzavam, correndo, enfermeiros e médicos diminutos demais para os satisfazer a todos. Ao fundo do barracão, arrimados aos cotovelos, de bruços, os antigos doentes, e feridos dos dias anteriores, olhavam inquietos para os novos sócios de infortúnio. A um lado, sobre o chão duro, corpos rígidos francamente batidos pelo sol, jaziam os cadáveres de alguns oficiais, o tenente-coronel Tupi, o major Queirós, os alferes Raposo, Neville, Carvalho e outros.

Soldados ofegantes e suarentos entravam e saíam intermitentemente, arcados sob padiolas. Despejavam-nas, volvendo, prestes, naquela azáfama fúnebre que ameaçava prolongar-se pelo dia todo. Porque até aquela hora a situação não melhorara. Persistia indecisa. Mantinha-se a réplica feroz dos adversários. Insistentes, imprimindo no tumulto a nota de uma monotonia cruel, reproduziam-se em todas as linhas os toques das cornetas, determinando as cargas; e estas realizavam-se, sucessivas, rápidas, impetuosas - pelotões, batalhões, brigadas, vagas de metal e flamas, fulgurando, rolando, arrebentando e detonando de encontro a represas intransponíveis.

As bombas de dinamite (foram arrojadas noventa nesse dia) estouravam de momento em momento, mas com absoluto insucesso. Adicionaram-se-lhes outros expedientes: latas de querosene derramadas por toda a orla da casaria, avivando os incêndios.

Este recurso bárbaro, porém, por sua vez, resultara inútil.

Por fim, às duas horas da tarde, se paralisou inteiramente o assalto; cessaram de todo as cargas; e no ânimo dos sitiantes, em franca defensiva nas posições primitivas, doíam desapontamentos de derrota. Defluindo da baixada, a leste da praça, continuou largo tempo a romaria penosa dos feridos, em busca do hospital de sangue. Em padiolas, em redes, ou suspensos pelos braços entre os companheiros, ascendiam exaustos, titubeantes, arrimando-se e cosendo-se às casas. E sobre eles, sobre as colinas, varrendo-as, sobre os morros artilhados, varejando-os, sobre o acampamento todo, ao cair da tarde, ao anoitecer e durante a noite inteira, visando todos os pontos da periferia do assédio, sibilando em todos os tons pelos ares, da zona reduzidíssima onde se acantonavam os jagunços, irrompiam as balas...
O combate fora cruento e estéril. Desfalcara-nos de quinhentos e sessenta e sete lutadores, sem resultado apreciável.

Como sempre, a vibração forte da batalha amortecera a pouco e pouco, atenuando-se em tiroteios escassos; e toda a noite passou, velando-a, a tropa combalida na expectativa cruel de novos recontros, novos sacrifícios inúteis e novos esforços malogrados.

Entretanto a situação dos sertanejos piorara. Tinham, com a perda da igreja nova, perdido as últimas cacimbas. Cercavam-nos braseiros enormes, progredindo-lhes em roda e avançando de três pontos - do norte, leste e oeste - obstringindo-os no último reduto.

Mas à madrugada de 2 os triunfadores fatigados despertaram com uma descarga desafiadora e firme.

\section{Notas de um diário}

Nesse dia...

Translademos, sem lhes alterar uma linha, as últimas notas de um “Diário”, escritas à medida que se desenrolavam os acontecimentos ${ }^{2}$.

\begin{abstract}
...Chegam à uma hora em grande número novos prisioneiros sintoma claro de enfraquecimento entre os rebeldes. Eram esperados. Agitara-se pouco depois do meio-dia uma bandeira branca no centro dos últimos casebres e os ataques cessaram imediatamente do nosso lado. Rendiam-se, afinal. Entretanto não soaram os clarins. Um grande silêncio avassalou as linhas e o acampamento.

A bandeira, um trapo nervosamente agitado, desapareceu; e, logo depois, dois sertanejos, saindo de um atravancamento impenetrável, se apresentaram ao comandante de um dos batalhões. Foram para logo conduzidos à presença do comandante-em-chefe, na comissão de engenharia.
\end{abstract}

\footnotetext{
${ }^{2}$ Estas notas, esboçadas durante o dia no acampamento e completadas à noite, no alto da Favela - têm valor da própria incorreção derivada do tumulto em que se traçaram.
} 


\section{Antônio, o Beatinho}

Um deles era Antônio, o Beatinho, acólito e auxiliar do Conselheiro. Mulato claro e alto, excessivamente pálido e magro, ereto o busto adelgaçado. Levantava, com altivez de resignado, a fronte. A barba rala e curta emoldurava-lhe o rosto pequeno animado de olhos inteligentes e límpidos. Vestia camisa de azulão e, a exemplo do chefe da grei, arrimava-se a um bordão a que se esteava, andando. Veio com outro companheiro, entre algumas praças, seguido de um séquito de curiosos.

Ao chegar à presença do general, tirou tranquilamente o gorro azul, de listras e bordas brancas, de linho; e quedou, correto, esperando a primeira palavra do triunfador.

Não foi perdida uma sílaba única do diálogo prontamente travado.

— Quem é você?

- Saiba o seu doutor general ${ }^{3}$ que sou Antônio Beato e eu mesmo vim por meu pé me entregar porque a gente não tem mais opinião e não aguenta mais.

E rodava lentamente o gorro nas mãos lançando sobre os circunstantes um olhar sereno.

— Bem. E o Conselheiro?...

— O nosso bom Conselheiro está no céu...

Morte de Conselheiro

Explicou então que aquele, agravando-se antigo ferimento, que recebera de um estilhaço de granada atingindo-o quando em certa ocasião passava da igreja para o Santuário, morrera a 22 de setembro, de uma disenteria, uma caminheira - expressão horrendamente cômica que pôs repentinamente um burburinho de risos irreprimidos naquele lance doloroso e grave.

O Beato não os percebeu. Fingiu, talvez, não os perceber. Quedou imóvel, face impenetrável e tranquila, de frecha sobre o general, olhar a um tempo humilde e firme. O diálogo prosseguiu:

\footnotetext{
${ }^{3}$ A extravagente denominação é textual. Devem recordar-se dela todos os que assistiram à interessante conferência. Ademais no que aí vai escrito só se altera a prosódia do sertanejo refratário aos rr, ll etc. A reprodução do diálogo é integral.
}

\section{— E os homens não estão dispostos a se entregarem?}

- Batalhei com uma porção deles para virem e não vieram porque há um bando lá que não querem. São de muita opinião. Mas não aguentam mais. Quase tudo mete a cabeça no chão de necessidade. Quase tudo está seco de sede...

— E não podes trazê-los?

— Posso não ${ }^{4}$. Eles estavam em tempo de me atirar quando saí...

— Já viu quanta gente aí está, toda bem armada e bem disposta?

— Eu fiquei espantado!

A resposta foi sincera, ou admiravelmente calculada. O rosto do altareiro desmanchou-se numa expressão incisiva e rápida, de espanto.

- Pois bem. A sua gente não pode resistir, nem fugir. Volte para lá e diga aos homens que se entreguem. Não morrerão. Garanto-lhes a vida. Serão entregues ao governo da República. E diga-lhes que o governo da República é bom para todos os brasileiros. Que se entreguem. Mas sem condições; não aceito a mais pequena condição..

O Beatinho, porém, recusava-se, obstinado, à missão. Temia os próprios companheiros. Apresentava as melhores razões para não ir.

Nessa ocasião interveio o outro prisioneiro, que até então permanecera mudo.

Viu-se, pela primeira vez, um jagunço bem nutrido e destacando-se do tipo uniforme dos sertanejos. Chamava-se Bernabé José de Carvalho e era um chefe de segunda linha.

Tinha o tipo flamengo, lembrando talvez, o que não é exagerada conjetura, a ascendência de holandeses que tão largos anos por aqueles territórios do Norte trataram com o indígena.

Brilhavam-lhe, varonis, os olhos azuis e grandes; o cabelo alourado revestia-lhe, basto, a cabeça chata e enérgica.

\footnotetext{
${ }^{4}$ Um traço do falar energético dos sertões, este sistema de negativa.
} 
Apresentou logo como credencial o mostrar-se duma linhagem superior. Não era um matuto largado. Era casado com uma sobrinha do capitão Pedro Celeste, de Bom Conselho...

Depois contraveio, num desgarre desabusado, insistindo com o Beatinho recalcitrante:

— Vamos! Homem! Vamos embora... Eu falo uma fala com eles.. deixe tudo comigo. Vamos !

E foram.

\section{Prisioneiros}

O efeito da comissão, porém, foi de todo em todo inesperado. O Beatinho voltou, passada uma hora, seguido de umas trezentas mulheres e crianças e meia dúzia de velhos imprestáveis. Parecia que os jagunços realizavam com maestria sem par o seu último ardil. Com efeito, viam-se libertos daquela multidão inútil, concorrente aos escassos recursos que acaso possuíam, e podiam, agora, mais folgadamente delongar o combate.

O Beatinho dera - quem sabe? - um golpe de mestre. Consumado diplomata, do mesmo passo poupara às chamas e às balas tantos entes miserandos e aliviara o resto dos companheiros daqueles trambolhos prejudiciais.

A crítica dos acontecimentos indica que aquilo foi, talvez, uma cilada.

Nem a exclui a circunstância de ter voltado o asceta ardiloso que a engenhara. Era uma condição favorável, adrede e astuciosamente aventurada como prova iniludível da boa fé com que agira. Mas, mesmo que assim não considerassem, alentava-o uma aspiração de todo admissível: fazer o último sacrifício em prol da crença comum: devotar-se, volvendo ao acampamento à sagração do martírio, que desejava, porventura, ardentemente, com o misticismo doentio de um iluminado. Não há interpretar de outra maneira o fato, esclarecido, ademais, pelo proceder do outro parlamentar que não voltara, permanecendo entre os lutadores, instruindo-os sem dúvida da disposição das forças sitiantes.

A entrada dos prisioneiros foi comovedora. Vinha solene, na frente o Beatinho, teso o torso desfibrado, olhos presos no chão, e com o passo cadente e tardo exercitado desde muito nas lentas procissões que compartira. $\mathrm{O}$ longo cajado oscilava-lhe à mão direita, isocronamente, feito enorme batuta, compassando a marcha verdadeiramente fúnebre. A um de fundo, a fila extensa, tracejando ondulada curva pelo pendor da colina, seguia na direção do acampamento, passando ao lado do quartel da primeira coluna e acumulando-se, cem metros adiante, em repugnante congérie de corpos repulsivos em andrajos.

Os combatentes contemplavam-nos entristecidos. Surpreendiam-se; comoviam-se. O arraial, in extremis, punha-lhes adiante, naquele armistício transitório, uma legião desarmada, mutilada, faminta e claudicante, num assalto mais duro que o das trincheiras em fogo. Custava-lhes admitir que toda aquela gente inútil e frágil saísse tão numerosa ainda dos casebres bombardeados durante três meses. Contemplando-lhes os rostos baços, os arcabouços esmirrados e sujos, cujos mulambos em tiras não encobriam lanhos, escaras e escalavros - a vitória tão longamente apetecida decaía de súbito. Repugnava aquele triunfo. Envergonhava. Era, com efeito, contraproducente compensação a tão luxuosos gastos de combates, de reveses e de milhares de vidas, o apresamento daquela caqueirada humana - do mesmo passo angulhenta e sinistra, entre trágica e imunda, passando-lhes pelos olhos, num longo enxurro de carcaças e molambos...

Nem um rosto viril, nem um braço capaz de suspender uma arma, nem um peito resfolegante de campeador domado: mulheres, sem número de mulheres, velhas espectrais, moças envelhecidas, velhas e moças indistintas na mesma fealdade, escaveiradas e sujas, filhos escanchados nos quadris desnalgados, filhos encarapitados às costas, filhos suspensos aos peitos murchos, filhos afastados pelos braços, passando; crianças, sem número de crianças; velhos, sem número de velhos; raros homens, enfermos opilados, faces túmidas e mortas, de cera, bustos dobrados, andar cambaleante.

Pormenorizava-se. Um velho absolutamente alquebrado, soerguindo por alguns companheiros, perturbava o cortejo. Vinha contrafeito. Forçava por se livrar e volver atrás os passos. Voltava-se, braços trêmulos e agitados, para o arraial onde deixara certo os filhos robustos, na última refrega. E chorava. Era o único que chorava. Os demais prosseguiam impassíveis. Rígidos anciãos, aquele desfecho cruento, culminando-lhes a velhice, era um episódio somenos entre 
os transes da vida nos sertões. Alguns respeitosamente se desbarretavam ao passarem pelos grupos de curiosos. Destacou-se, por momentos, um. Octogenário, não se lhe dobrava o tronco. Marchava devagar e de quando em quando parava. Considerava por instantes a igreja e reatava a marcha; para estacar outra vez, dados alguns passos, voltar-se lançando novo olhar ao templo em ruínas e prosseguir, intermitentemente, à medida que se escoavam pelos seus dedos as contas de um rosário. Rezava. Era um crente. Aguardava talvez ainda o grande milagre prometido...

Alguns enfermos graves vinham carregados. Caídos logo aos primeiros passos, passavam, suspensos pelas pernas e pelos braços, entre quatro praças. Não gemiam, não estortegavam; lá se iam imóveis e mudos, olhos muito abertos e muito fixos, feito mortos. Aos lados, desorientadamente, procurando os pais que ali estavam entre os bandos ou lá embaixo mortos, adolescentes franzinos, chorando, clamando, correndo. Os menores vinham às costas dos soldados agarrados às grenhas despenteadas há três meses daqueles valentes que havia meia hora ainda jogavam a vida nas trincheiras e ali estavam, agora, resolvendo desastradamente, canhestras amassecas, o problema difícil de carregar uma criança. Uma megera assustadora, bruxa rebarbativa e magra - a velha mais hediond talvez destes sertões - a única que alevantava a cabeça espalhando sobre os espectadores, como faúlhas, olhares ameaçadores; e nervosa e agitante, ágil apesar da idade, tendo sobre as espáduas de todo despidas, emaranhados, os cabelos brancos e cheios de terra rompia, em andar sacudido, pelos grupos miserandos, atraindo a atenção geral. Tinha nos braços finos uma menina, neta, bisneta, tataraneta talvez. E essa criança horrorizava. A sua face esquerda fora arrancada, havia tempos, por um estilhaço de granada; de sorte que os ossos dos maxilares se destacavam alvíssimos, entre os bordos vermelhos da ferida já cicatrizada... A face direita sorria. E era apavorante aquele riso incompleto e dolorosíssimo aformoseando uma face e extinguindo-se repentinamente na outra, no vácuo de um gilvaz.

Aquela velha carregava a criação mais monstruosa da campanha. Lá se foi com o seu andar agitante, de atáxica, seguindo a extensa fila de infelizes...

Esta parara adiante, a um lado das tendas do esquadrão de cavalaria, represando entre as quatro linhas de um quadrado. Via-se, então, pela primeira vez, em globo, a população de Canudos; e, à parte as variantes impressas pelo sofrer diversamente suportado, sobressaía um traço de uniformidade rara nas linhas fisionômicas mais características. Raro um branco ou negro puro. Um ar de família em todos delatando, iniludível, a fusão perfeita de três raças.

Predominava o pardo lídimo, misto de cafre, português e tapuia faces bronzeadas, cabelos corredios e duros ou anelados, troncos deselegantes; e aqui, e ali, um perfil corretíssimo recordando o elemento superior da mestiçagem. Em roda, vitoriosos, díspares e desunidos, o branco, o negro, o cafuz e o mulato proteiformes com todas as gradações da cor... Um contraste: a raça forte e íntegra abatida dentro de um quadrado de mestiços indefinidos $e$ pusilânimes. Quebrara-a de todo a luta. Humilhava-se. Do ajuntamento miserando partiam pedidos flébeis e lamurientos, de esmola... Devoravam-na a fome e a sede de muitos dias.

O comandante geral concedera naquele mesmo dia aos últimos rebeldes um armistício de poucas horas. Mas este só teve o efeito contraproducente de retirar do trecho combatido aqueles prisioneiros inúteis.

Ao cair da tarde estavam desafogados os jagunços.

Deixaram que se esgotasse a trégua. E quando lhes anunciou o termo uma intimativa severa de dois tiros de pólvora seca seguidos logo de outro, de bala rasa, estenderam sobre os sitiantes uma descarga divergente e firme.

A noite de 2 entrou, ruidosamente, sulcada de tiroteios vivos. 


\section{Capítulo VI}

\section{O fim}

Não há relatar o que houve a 3 e a 4.

A luta, que viera perdendo dia a dia o caráter militar, degenerou, ao cabo, inteiramente. Foram-se os últimos traços de um formalismo inútil: deliberações de comando, movimentos combinados, distribuições de forças, os mesmos toques de cornetas, e por fim a própria hierarquia, já materialmente extinta num exército sem distintivos e sem fardas.

Sabia-se de uma coisa única: os jagunços não poderiam resistir por muitas horas. Alguns soldados se haviam abeirado do último reduto e colhido de um lance a situação dos adversários. Era incrível: numa cava quadrangular, de pouco mais de metro de fundo, ao lado da igreja nova, uns vinte lutadores, esfomeados e rotos, medonhos de ver-se, predispunham-se a um suicídio formidável. Chamou-se aquilo o "hospital de sangue" dos jagunços. Era um túmulo. De feito, lá estavam, em maior número, os mortos, alguns de muitos dias já, enfileirados ao longo das quatro bordas da escavação e formando o quadrado assombroso dentro do qual uma dúzia de moribundos, vidas concentradas na última contração dos dedos nos gatilhos das espingardas, combatiam contra um exército.

E lutavam com relativa vantagem ainda.

Pelos menos fizeram parar os adversários. Destes os que mais se aproximaram lá ficaram, aumentando a trincheira sinistra de corpos esmigalhados e sangrentos. Viam-se, salpintando o acervo de cadáveres andrajosos dos jagunços, listras vermelhas de fardas e entre elas as divisas do sargento-ajudante do $39^{\circ}$, que lá entrara, baqueando logo. Outros tiveram igual destino. Tinham a ilusão do último recontro feliz e fácil: romperam pelos últimos casebres envolventes, caindo de chofre sobre os titãs combalidos, fulminando-os, esmagando-os...

Mas eram terríveis lances, obscuros para todo o sempre. Raro tornavam os que os faziam. Aprumavam-se sobre o fosso e sopeava-lhes o arrojo o horror de um quadro onde a realidade tangível de uma trincheira de mortos, argamassada de sangue e esvurmando pus, vencia todos os exageros da idealização mais ousada. E salteava-os a atonia do assombro...

\section{Canudos não se rendeu}

Fechemos este livro.

Canudos não se rendeu. Exemplo único em toda a História, resistiu até ao esgotamento completo. Expugnado palmo a palmo, na precisão integral do termo, caiu no dia 5, ao entardecer, quando caíram os seus últimos defensores, que todos morreram. Eram quatro apenas: um velho, dois homens feitos e uma criança, na frente dos quais rugiam raivosamente 5 mil soldados.

Forremo-nos à tarefa de descrever os seus últimos momentos. Nem poderíamos fazê-lo. Esta página, imaginamo-la sempre profundamente emocionante e trágica; mas cerramo-la vacilante e sem brilhos.

Vimos como quem vinga uma montanha altíssima. No alto, a par de uma perspectiva maior, a vertigem...

Ademais, não desafiaria a incredulidade do futuro a narrativa de pormenores em que se amostrassem mulheres precipitando-se nas fogueiras dos próprios lares, abraçadas aos filhos pequeninos...

E de que modo comentaríamos, com a só fragilidade da palavra humana, o fato singular de não aparecerem mais, desde a manhã de 3 , os prisioneiros válidos colhidos na véspera, e entre eles aquele Antônio Beatinho, que se nos entregara, confiante - e a quem devemos preciosos esclarecimentos sobre esta fase obscura da nossa História?

Caiu o arraial a 5. No dia 6 acabaram de o destruir desmanchando-lhe as casas, 5.200, cuidadosamente contadas.

\section{O cadáver do Conselheiro}

Antes, no amanhecer daquele dia, comissão adrede escolhida descobrira o cadáver de Antônio Conselheiro ${ }^{1}$.

\footnotetext{
${ }^{1}$ Trecho de parte de combate, do comandante da $1^{\text {a }}$ coluna: “... pelo que ordenei que se retirasse daquela cova com todo o cuidado, o defunto, e o levassem para a praça e assim se
} 
Jazia num dos casebres anexos à latada, e foi encontrado graças à indicação de um prisioneiro. Removida breve camada de terra, apareceu no triste sudário de um lençol imundo, em que mãos piedosas haviam desparzido algumas flores murchas, e repousando sobre uma esteira velha, de tábua, o corpo do "famigerado e bárbaro" agitador. Estava hediondo. Envolto no velho hábito azul de brim americano, mãos cruzadas ao peito, rosto tumefacto e esquálido, olhos fundos cheios de terra - mal o reconheceram os que mais de perto o haviam tratado durante a vida.

Desenterraram-no cuidadosamente. Dádiva preciosa — único prêmio, únicos despojos opimos de tal guerra! — , faziam-se mister os máximos resguardos para que se não desarticulasse ou deformasse, reduzindo-se a uma massa angulhenta de tecidos decompostos.

Fotografaram-no depois. E lavrou-se uma ata rigorosa firmando a sua identidade: importava que o país se convencesse bem de que estava, afinal, extinto aquele terribilíssimo antagonista.

Restituíram-no à cova. Pensaram, porém, depois, em guardar a sua cabeça tantas vezes maldita - e, como fora malbaratar o tempo exumandoo de novo, uma faca jeitosamente brandida, naquela mesma atitude, cortoulha; e a face horrenda, empastada de escaras e de sânie, apareceu ainda uma vez ante aqueles triunfadores...

Trouxeram depois para o litoral, onde deliravam multidões em festa, aquele crânio. Que a ciência dissesse a última palavra. Ali estavam, no relevo de circunvoluções expressivas, as linhas essenciais do crime e da loucura...

poder melhor verificar a identidade da pessoa: tendo-se reconhecido ser o do famigerado e bárbaro Antônio Vicente Mendes Maciel (vulgo Bom Jesus Conselheiro), como consta da ata lavrada; mandei-o fotografar para terem certeza de ser ele, aqueles que o conheceram".

\section{Capítulo VII}

\section{Duas linhas}

É que ainda não existe um Maudsley para as loucuras e os crimes das nacionalidades... 